\title{
THE IMPACT OF WORKLOAD ON NURSE PERFORMANCE IN INTENSIVE CARE UNIT AT MUHAMMADIYAH GAMPING HOSPITAL
}

\author{
Sitti Fatmalla Salim, Elsye Maria Rosa \\ Masters Program in Hospital Management, Universitas \\ Muhammadiyah Yogyakarta
}

\begin{abstract}
Background: Work performance of nurses is critical in the hospital care delivery, as it affects directly the hospital performance. This study aimed to examine the effect of workload on work performance among nurses working at the Intensive Care Unit (ICU) at Muhammadiyah Gamping Hospital Yogyakarta.

Subjects and Method: This was an observational study conducted at Muhammadiyah Gamping Hospital, Yogyakarta. A sample of nurses working at the ICU was selected for this study. The dependent variable was work performance. The independent variable was workload, either quantitative, qualitative, or both. The data were collected by questionnaire and analyzed by a linear regression.

Results: The effect of combined quantitative and qualitative workload on work performance was statistically significant $(p=0.047)$. But the effect of single quantitative or qualitative workload on work performance was statistically nonsignificant.

Conclusion: The effect of combined quantitative and qualitative workload on work performance was statistically significant, but the effect of single quantitative or qualitative workload on work performance was statistically non-significant.
\end{abstract}

Keywords: work performance, workload, intensive care unit, nurse

\section{Correspondence:}

Sitti Fatmalla Salim. Masters Program in Hospital Management, Universitas Muhammadiyah Yogyakarta, Jl. Lingkar Selatan, Tamantirto, Kasihan, Bantul, Yogyakarta. Email: fatmallasitti23@gmail.com. Mobile: 081230926066. 